\title{
KNOWLEDGE ATTITUDE TO MODERN FAMILY PLANNING METHODS IN ABRAKA COMMUNITIES, DELTA STATE, NIGERIA.
}

\author{
I.R.Aninyei ${ }^{1}$, I. Onyesom ${ }^{2}$, H.O. Ukuhor ${ }^{3}$, U.E.Uzuegbu ${ }^{2}$, M.I. Ofili ${ }^{4}$ and E.B. Anyanwu $^{5}$
}

\begin{abstract}
Objective:. To assess the level of regard and misconceptions of modern family planning methods in Abraka communities. Methods: The interviewer's administered questionnaire method was used to gather the required information from 657 respondents randomly chosen from PO, Ajalomi, Erho, Oria, Otorho, Umeghe, Urhuoka and Uruagbesa communities in Abraka kingdom. Results: Results show that $75.3 \%$ of those interviewed were aware of modern family planning but only $42.9 \%$ were using it to plan their families. Those using condom, safe periods and withdrawal constitute $32.6 \%$ of the $42.9 \%$ figure. Thus, data indicate a fairly high degree of awareness but little regard for family planning.

Conclusion: Campaigns should be organized in order to educate Abraka communities on the benefits and need for family planning. Government should provide quality, comprehensive and subsidized family planning services. In addition, research efforts should be intensified on how to take advantage of the traditional methods of family planning to systematically introduce the modern method, so as to gradually eliminate the associated bias and misconceptions associated with modern methods of family planning.
\end{abstract}

Keywords: Abraka, Family planning, Questionnaire, Respondents, Condom, Safe periods.

\section{Introduction}

The current realization that socio-economic development and well being of a society can be affected by astronomical increase in population has led to the establishment of family planning programmes. Family planning is a way of living that is adopted voluntarily upon the basis of knowledge attitude and responsible decisionmaking by individuals or couples in order to pin the number, timing and spacing of the children that they want, so as to promote the health and welfare of the family group, and contribute to the advancement of the society.

Basically, there are two major methods of family planning-the traditional and modern methods. Attempts to control increase in population started from the early men. Therefore, birth control is as old as man himself. Evidence from medical history indicates that our forefathers did space their children through traditional means, and Delano (1) has observed that traditional methods of family planning had been handed down either verbally or in writing from generation to generation as far back as the Stone Age. Before the introduction of modern methods, Africans had methods of fertility regulation. Nigerian culture includes many myths, rituals and the use of herbs in attempts to regulate women's fertility. Although many of these traditional methods of family planning have no harmful effects on a woman's health, some however, do have dangerous or counterproductive effects. In addition, the complete effectiveness of many of the traditional methods has remained doubtful. Albeit, the modern method of family planning and associated programmes have helped women around the world to avoid 400 million unwanted pregnancies, and so, the lives of many women have been saved from high risk pregnancy or unsafe abortion. Hatcher (2) reported that

Corresponding to: I. Onyesom Postal: P.O. Box 144, Abraka, Delta State, Nigeria. Email: onvesominno@yahoo.co.uk, Tel: +2348030528016.

${ }^{1}$ Department of Physiology, ${ }^{2}$ Department of Medical Biochemistry, ${ }^{3}$ Department of Community Medicine, ${ }^{4}$ Department of Nursing Science, ${ }^{5}$ Department of Family Medicine, Delta State University, Abraka, Nigeria. if all women could avoid high risk pregnancies, the number of maternal deaths could fall by one quarter.

Abraka is situated in the Central Senatorial District of Delta State. It has about eight communities largely dominated by the Urhobos. The Urhobos have strong preference for polygamy and they believe that children are blessings from God and insurance against old age. This study evaluates the degree of awareness, misconceptions, and attitudes to modern family planning methods in Abraka communities.

\section{Methodology}

The interviewer's administered questionnaire method (3) was used to obtain information on demographic data, and the degree of awareness, misconceptions and attitudes to modern family planning. A total of 657 (293 men and 364 women) respondents, comprising of the married, widows, widowers, and divorcees, were randomly selected from the eight communities (Abraka PO, $n=203: 98 \mathrm{M}$, 105F; Ajalomi, $\mathrm{n}=86: 36 \mathrm{M}, 50 \mathrm{~F}$; Erho, $\mathrm{n}=72: 31 \mathrm{M}$, 41F; Oria, $\mathrm{n}=98: 42 \mathrm{M}, 56 \mathrm{~F}$; Otorho, $\mathrm{n}=41: 18 \mathrm{M}, 23 \mathrm{~F}$; Umeghe, $\mathrm{n}=56: 25 \mathrm{M}, 31 \mathrm{~F}$; Urhuoka, $\mathrm{n}=63: 26 \mathrm{M}, 37 \mathrm{~F}$; and Uruagbesa, $\mathrm{n}=38: 17 \mathrm{M}, 21 \mathrm{~F})$ in Abraka Kingdom. The sample size (657 respondents) is a good representation of the target population (married, widows, widowers and divorcees) of the study area as judged by statistical data.

\section{Results}

The results obtained from the study are presented on Tables 1 and 2 . Table 1 , shows the demographic information of the respondents, and this reveals a reasonable level of illiteracy, as those respondents with no formal education stood at $14.2 \%$, while those with primary, secondary, and tertiary education were $29.5 \%$, $32.7 \%$, and $23.6 \%$, respectively. Majority (74.6\%) had low financial strength (family income of less than N50,000.00/month). $56.3 \%$ of the respondents were from polygamous families, and $92.2 \%$ belong to families having over 6 members.

Our data (Table 1) indicate that $24.7 \%$ of those interviewed are not aware of modern family planning and associated programmes. Out of those who were aware, 
only $42.9 \%$ of them are currently using family planning methods to plan their families. Determination of the different family planning methods being used by those involved shows that $20.7 \%, 6.3 \%, 3.4 \%, 0.5 \%, 29.8 \%$, $13.9 \%$, and $25.5 \%$ were using condoms, oral contraceptives (OCPs), intrauterine device (IUD or coil), tubal ligation/vasectomy (sterilization), natural family planning (NFP or safe periods), injectables, and withdrawal (coitus interruptions), respectively (Table 2). The number of individuals who did not have any unwanted pregnancy while using the method of family planning was used to estimate the degree of compliance and success of each method. Such estimates show that condom use had $61.3 \%$ success, while OCPs, IUD, sterilization, NFP, injectables, and withdrawal methods gave $76 \%$, and their average failure rate was put at $44.4 \%$.

Table 1: Data on socio-demographic information obtained from respondents in Abraka Communities.

\begin{tabular}{|c|c|c|c|c|c|c|c|c|}
\hline & \multicolumn{3}{|c|}{ Communities in Abraka kingdom } & \multirow[b]{2}{*}{$\begin{array}{l}\text { Oria } \\
(n=98)\end{array}$} & \multirow[b]{2}{*}{$\begin{array}{l}\text { Otorho } \\
(n=41)\end{array}$} & \multirow[b]{2}{*}{$\begin{array}{l}\text { Umeghe } \\
(n=56)\end{array}$} & \multirow[b]{2}{*}{$\begin{array}{l}\text { Urhuoka } \\
(n=63)\end{array}$} & \multirow[b]{2}{*}{$\begin{array}{l}\text { Uruagbesa } \\
(\mathrm{n}=38)\end{array}$} \\
\hline & $\begin{array}{l}\text { P.O } \\
(n=203)\end{array}$ & $\begin{array}{l}\text { Ajalomi } \\
(\mathrm{n}=86)\end{array}$ & $\begin{array}{l}\text { Erho } \\
(n=72)\end{array}$ & & & & & \\
\hline \multicolumn{9}{|l|}{$\operatorname{Age}(y r)$} \\
\hline $20-25$ & 21 & 8 & 6 & 19 & 7 & 9 & 12 & 5 \\
\hline $26-30$ & 33 & 31 & 23 & 28 & 12 & 28 & 29 & 13 \\
\hline $31-35$ & 76 & 28 & 27 & 32 & 10 & 10 & 11 & 8 \\
\hline $36-40$ & 63 & 11 & 8 & 9 & 7 & 5 & 6 & 6 \\
\hline $41-45$ & 6 & 6 & 5 & 6 & 3 & 3 & 2 & 3 \\
\hline$\geq 46$ & 4 & 2 & 3 & 4 & 2 & 1 & 3 & 3 \\
\hline \multicolumn{9}{|l|}{ Sex } \\
\hline Male & 98 & 36 & 31 & 42 & 18 & 25 & 26 & 17 \\
\hline Female & 105 & 50 & 41 & 56 & 23 & 31 & 37 & 21 \\
\hline \multicolumn{9}{|l|}{ Marital status } \\
\hline Married & 125 & 66 & 63 & 75 & 32 & 42 & 50 & 29 \\
\hline Widow & 21 & 8 & 5 & 8 & 6 & 7 & 6 & 4 \\
\hline Widower & 6 & 3 & 1 & 2 & 1 & 2 & 3 & - \\
\hline Divorcee & 51 & 9 & 3 & 13 & 2 & 5 & 4 & 5 \\
\hline \multicolumn{9}{|l|}{ Education } \\
\hline None & 7 & 12 & 16 & 8 & 16 & 11 & 5 & 18 \\
\hline Primary & 23 & 31 & 31 & 29 & 12 & 32 & 23 & 13 \\
\hline Secondary & 56 & 33 & 20 & 46 & 11 & 12 & 30 & 7 \\
\hline Tertiary & 117 & 10 & 5 & 15 & 2 & 1 & 5 & - \\
\hline \multicolumn{9}{|l|}{ Religion } \\
\hline Christianity & 196 & 76 & 68 & 91 & 19 & 32 & 52 & 17 \\
\hline Islam & 2 & - & - & 1 & - & - & 1 & - \\
\hline Traditional & 4 & 7 & 3 & 4 & 22 & 23 & 8 & 21 \\
\hline None & 1 & 3 & 1 & 2 & - & 1 & 2 & - \\
\hline \multicolumn{9}{|l|}{ Family income (N/month) } \\
\hline$\leq 9,99.99$ & 53 & 37 & 44 & 37 & 18 & 21 & 29 & 17 \\
\hline $10,000.00-49,999.99$ & 66 & 42 & 19 & 42 & 20 & 28 & 31 & 21 \\
\hline $50,000.00-99,999.99$ & 71 & 5 & 6 & 12 & 3 & 5 & 2 & - \\
\hline $100,000.00-199,999.99$ & 10 & 2 & 4 & 6 & - & 2 & 1 & - \\
\hline$\geq 200,000.00$ & 3 & - & - & 1 & - & - & - & - \\
\hline \multicolumn{9}{|l|}{ Family size } \\
\hline $1-5$ & 12 & 6 & 4 & 2 & 5 & 9 & 7 & 3 \\
\hline $6-10$ & 186 & 29 & 38 & 42 & 9 & 20 & 33 & 15 \\
\hline $11-15$ & 2 & 38 & 26 & 46 & 24 & 26 & 21 & 19 \\
\hline$\geq 16$ & - & 13 & 4 & 8 & 3 & 1 & 2 & 1 \\
\hline \multicolumn{9}{|l|}{ Nature of family } \\
\hline Monogamy & 96 & 33 & 24 & 46 & 7 & 23 & 46 & 12 \\
\hline Polygamy & 107 & 53 & 48 & 52 & 34 & 33 & 17 & 26 \\
\hline \multicolumn{9}{|l|}{ Family planning use } \\
\hline Yes & 82 & 17 & 21 & 31 & 6 & 19 & 29 & 3 \\
\hline No & 121 & 69 & 51 & 67 & 35 & 37 & 34 & 35 \\
\hline \multicolumn{9}{|l|}{ Why no family planning use } \\
\hline Fear of side effects & 45 & 5 & 6 & 17 & 1 & 3 & 6 & 1 \\
\hline Religious prohibition & - & - & - & 1 & - & - & - & - \\
\hline Whiteman's deceit & 10 & 4 & 2 & 3 & 1 & 4 & 6 & 1 \\
\hline Needs Female children & 11 & 1 & 3 & 4 & 1 & 3 & 3 & 1 \\
\hline Needs male children & 33 & 4 & 11 & 26 & 2 & 7 & 10 & 2 \\
\hline Reduces coital satisfaction & 6 & - & 3 & 2 & - & - & 1 & - \\
\hline Spouse hates the idea & 5 & 1 & 10 & 4 & 1 & 2 & 3 & 1 \\
\hline Not aware of it & 11 & 54 & 16 & 10 & 29 & 18 & 5 & 29 \\
\hline
\end{tabular}


Table 2: Use of family planning methods among respondents in Abraka communities.

\begin{tabular}{|c|c|c|c|c|c|c|c|}
\hline \multirow{2}{*}{$\begin{array}{l}\text { Communities } \\
\text { in Abraka }\end{array}$} & \multicolumn{7}{|c|}{ Family Planning Methods } \\
\hline & Condom & OCPs & IUD & Sterilization & Safe periods & Injectables & Withdrawal \\
\hline Abraka PO $(n=82)$ & 12 & 4 & 2 & 1 & 18 & 14 & 3 \\
\hline Ajalomi $(n=17)$ & 3 & 1 & - & - & 8 & 3 & 2 \\
\hline Erho $(n=21)$ & 6 & 1 & - & - & 9 & 1 & 4 \\
\hline Oria $(n=31)$ & 8 & 2 & 2 & - & 6 & 9 & 4 \\
\hline Otorho $(n=6)$ & 2 & - & - & - & 3 & - & 1 \\
\hline Umeghe $(n=19)$ & 4 & 3 & 1 & - & 7 & - & 4 \\
\hline Urhuoka $(n=29)$ & 8 & 2 & 2 & - & 9 & 2 & 6 \\
\hline Uruagbesa $(n=3)$ & - & - & - & - & 2 & - & 1 \\
\hline$\%$ Compliance and success* & 61.3 & 74.6 & 68.7 & 100 & 52.4 & 93.7 & 53.2 \\
\hline
\end{tabular}

OCPs-Oral contraceptive pills, IUD-Intrauterine device (coil), *Determined by the number who did not have any unwanted pregnancy

Majority of those who are aware of family planning methods, but are not using any had varied reasons which include: fear of side effects: $30.3 \%$, religious prohibition: $0.4 \%$, Whiteman's deceit: $16.2 \%$, needs female $(5.1 \%)$ or male $(34.3 \%)$ children, reduces coital satisfaction: $4.3 \%$, spouse hates the idea: $16.3 \%$.

\section{Discussion}

Evidence from the analysis of the information obtained indicates a fair degree of awareness but poor attitude to family planning. Data also demonstrate skeptical behaviours toward some family planning methods and strong desire to have as many children as God provides irrespective of the socio-economic implications. Little regard for family planning could cause food shortages, starvation, unemployment, declining soil fertility, low standard of living, high rate of disease prevalence, increase in the cases of unplanned (unwanted) pregnancies and high risk abortions among others. Our interactions and observations show that overall, there were high rates of malnutrition, child neglect (abuse), poverty, and infectious disease morbidity. Life expectancy was generally low. Many youths engage themselves in undignifying jobs and women do hard, daily paid jobs exclusively meant for men. Drug abuse, alcoholism, and crime rates are high. Speculations indicate increasing cases of unwanted (unplanned) pregnancies and high risk abortions in these communities.

Although contraceptive prevalence rates have increased dramatically in the last thirty years, an estimated 26-53 million abortions are still performed annually worldwide (4). Those abortions that are unsafe-performed by untrained practitioners working in unhygienic conditions - are responsible for between 50,000 and 100,000 preventable deaths of women each year (5). Most of this mortality occurs in the developing world. The World Health Organisation (5) reported that the risk of death arising from unsafe abortion in Africa, Asia, Europe, and Latin America are 1 in 150, $I$ in 250, 1 in 2,600, and 1 in 800 , respectively.
The high rate of women who resort to unsafe abortion is a powerful reminder that women need access to a wide range of family planning methods to help them safely control their own fertility (6). The fact that so many women risk death, injury, and social or criminal consequences to terminate a pregnancy demonstrates clearly how desperately these women wish to delay or avoid having children.

During our study, we observed that many respondents want to space their children, and control (limit) the number, but do not want to use a modern method because of several misconceptions, and these observations agree with the findings of Lamprecht and Grummer-Strawn (7).

As a follow-up, we recommend that all levels of government should provide higher quality, more comprehensive and well-subsidized family planning services which should be given priority in maternal child health units. Campaigns and seminars on family planning programmes and need should be organized in order to educate community leaders and lay public about the benefits of modern family planning. School children should be educated about the family in today's society and the importance of planning it. Research efforts should be intensified on how to take advantage of non-harmful traditional practices and rituals to promote the acceptance of modern family planning.

\section{References}

1. Delano, G. Guide to Family Planning. New Edition, Ibadan, Spectrum Books, Ltd., 1990.

2. Hatcher, R.A. Contraceptive Technology. New York, Irvington, 1989.

3. Benson, J. et al., Meeting women's Needs for Post-Abortion Family Planning: Framing the Questions. Carrboro, NC: IPAS, 1992.

4. Hensaw, S.K. and Morrow, E. Induced Abortion: a World Review. 1990 supplement. New York, Alan Guttmacher Institute, 1990.

5. World health Organization (WHO). Abortion: A Tabulation of Available Data on the Frequency and Mortality of Unsafe Abortion. $2^{\text {nd }}$ edition. Geneva, WHO, 1993.

6. Salter, C., Johnston, H.B. and Hengen, N. New Directions in Emergency care: Saving Women's Lives. Population Reports, Series L, No. 10. Baltimore: John Hopkins School of Public Health, Population Information Program, October 1996.

7. Lamprecht, V. and Grummer-Strawn, L. Development of a new algorithm to identify the fertile phase of the menstrual cycle. Georgetown University Medical Center, Institute for Reproductive Health. Unpublished paper.

Received 31 July 2007; Revised 20 January 2008; Accepted 20 February 2008 